prising increase in the size of the Pelican colony. Last year 19 young Pelicans were raised there, and they were three weeks later than elsewhere, suggesting that this may have been a second attempt at rssting that year. This year over 300 Pelicans were hatched at this colony, and I banded 219 of them. It may well be that these are the same birds that once nested on Last Mountain Lake until discouraged by successive years of June flooding, and perhaps by the increasing number of fishermen's encampments at the northeast part of the lake. The Cormorant colony on Little Quill also increased in size, coincident with a sharp decrease in the numbers of this species on Last Mountain Lake.

The tiny island of nettles and rose bushes on Last Mountain which had 8 White-vinged Scoter nests in 1955 ( 5 of the females caught and banded, see "Blue Jay", Vol. XIII, Oct. 1955, p. 28), and 5 Scoter nests in 1956 (4 females caught and banded), had 4 Scoter nssts when visited this year. Two of the three females caught proved to have been banded on the same island the previous year

Continuous high winds marred the visit to Redberry Lake, where 123 White Pelicans were banded at the only island (of four) that could be visited.

My small sample of hawk nests, while not large enough to allow of definite conclusions, nevertheless suggested poor success and this might be linked to the low numbers of ground squirrels in recent years. A Marsh Hawk at Dilke had only three ycung; the youngest of three Swainson Hawks at Dilke was dead at the fcot of the tree; the three Red-tailed Hawk nest located near Saltcoats by Billy Horseman raised vily one young each. Similarly a Horned Owl nest at Dilke had only one young.

Two Pigeon Hawks nesting in an old Magpie nest west of Regina Beach were banded on July 7. This nest had been found by Doug Gilroy, and independently by S. R. Belcher, J. E. Belcher and Margaret Belcher.

\title{
Crippled Owl Nesting
}

By RICHARD W. FYFE, Saskatchewan Museum of Natural History

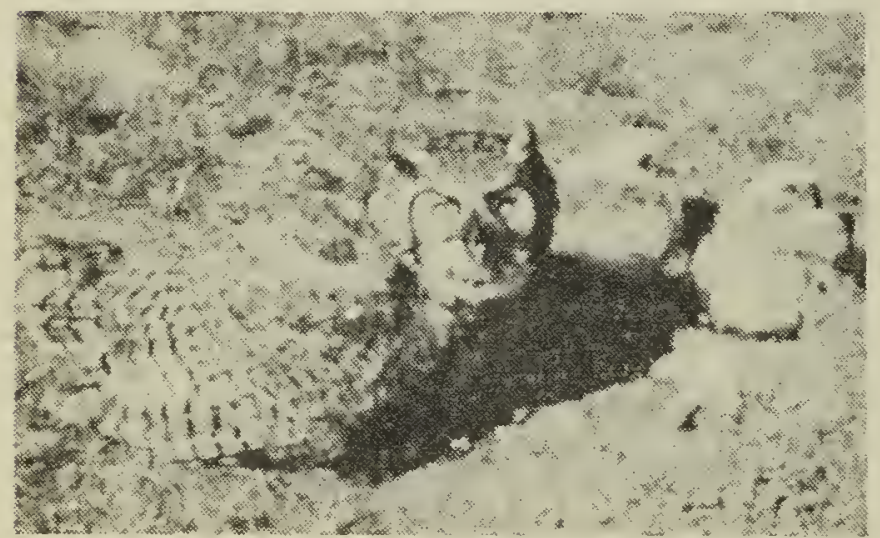

On May 7, 1957, I found the nest site of a Great Horned Owl (Bubo virginianus) on the ground near an abandoned salt mine south of Merid, Saskatchewan. The nest was within 30 yards of vacated mine buildings and machinery in an area of prairie entirely devoid of trees, the closest being more than a mile away. One of the parents and two young owls were found at the site which was a slight depression with no nest material (see photo). The scraped ground of the nest site measured 23 by 17 inches. The partly-eaten remains of two immature jack rabbits lay to one side of the nest; about five feet from the nest I found a smal fragment of a white egg-shell evid ently from an owl egg.

As can readily be seen by th accompanying photograph the paren at the nest was very reluctant $t$ move. Eventually it did retreat from the nest and proved to be frightless It was caught and examination of th left wing disclosed an extensive in jury to the radius and ulna whic was almost completely healed. Sca tissue about one inch in length over lay the wound and deep red colorin surrounded the scar. There appeare to be no infection. Presumably th unusual selection of the nest site wa the result of one parent being crip pled. However a review of the liter ature indicates ground nesting doe occur so this may have been th normal choice of these birds.

Although only one adult was see at the nest the other parent mus have been nearby as it seems unlikel that the crippled bird could have pro vided food for the young. Certainl the jack rabbits must have been pro vided by another bird. 